\title{
ATP and GTP Stimulate Membrane-bound but not Digitonin-solubilized $\beta$-Glucan Synthases from Saprolegnia monoica
}

\author{
By MICHEL FÈVRE \\ Laboratoire de Mycologie associé au CNRS no. 44, Université Claude Bernard, Bâtiment 405, \\ 43 Bd du 11 Novembre 1918, 69622 Villeurbanne Cédex, France.
}

(Received 30 May 1984; revised 6 August 1984)

\begin{abstract}
Glucan synthases of Saprolegnia assayed in the presence of $\mathrm{MgCl}_{2}[(1 \rightarrow 4)-\beta$-glucan production] were stimulated by ATP or GTP, while the non-phosphorylating nucleotide analogues adenylyl $(\beta, \gamma$-methylene)diphosphonate and guanylyl $(\beta, \gamma$-methylene)diphosphonate did not stimulate glucan synthesis. The analogues adenosine $5^{\prime}-O-\left(3\right.$-thiotriphosphate) and guanosine $5^{\prime}-O-(3-$ thiotriphosphate) stimulated the enzyme activity but to a lesser extent than the nucleotides. The activators stimulated membrane-bound enzymes, particularly those equilibrating at the endoplasmic reticulum density in sucrose gradients. Glucan synthases solubilized by digitonin were not stimulated by nucleotides. Nucleotides, whose action seems to be related to the integrity of the phosphate groups, may produce their stimulative effect by increasing the translocation of the substrate through membranes to the enzymes.
\end{abstract}

\section{INTRODUCTION}

In Saprolegnia, the structural components of the cell wall are $(1 \rightarrow 3)-\beta$ - and $(1 \rightarrow 6)-\beta$-glucans and cellulose (Bartnicki-Garcia, 1968). We have previously reported that cell-free extracts of Saprolegnia monoica utilize UDPglucose as substrate to synthesize $(1 \rightarrow 3)-\beta$ - or $(1 \rightarrow 4)-\beta$-glucans according to the assay conditions (Fèvre, $1979 a$; Fèvre \& Rougier, 1981). The (1-4)- $\beta$-glucan synthases of Saprolegnia are also activated by the presence of ATP or GTP (Fèvre \& Rougier, 1981; Fèvre, 1983).

Regulation by nucleotides of glucan synthases from Saccharomyces cerevisiae and Acetobacter xylinum has recently been reported (Shematek \& Cabib, 1980; Shematek et al., 1980; Aloni et al., 1982). In Saccharomyces, GTP and other phosphorylated compounds (ATP, nucleotide analogues, inorganic pyrophosphate) activate $(1 \rightarrow 3)$ - $\beta$-glucan synthases by binding to the enzymes (Notario et al., 1982). In Acetobacter, GTP activation of $(1 \rightarrow 4)-\beta$-glucan synthase depends on the presence of an easily solubilizable protein factor (Aloni et al., 1983). The aim of this work was to elucidate and compare the stimulation by GTP and ATP of glucan synthesis by particulate and soluble enzymes of Saprolegnia.

\section{METHODS}

Culture methods. Saprolegnia monoica Pringsheim (no. 53967 Dick; CBS Baarn, The Netherlands) was grown in the liquid medium of Machlis (1953) and harvested after $4 \mathrm{~d}$ incubation at $23^{\circ} \mathrm{C}$.

Preparation of particulate enzymes. Mycelia were washed and mixed in buffer $(0.01 \mathrm{M}$ - Tris/ $\mathrm{HCl}, 0.5 \mathrm{M}$-sorbitol, $0.001 \mathrm{M}$-EDTA, pH 7.2) containing $1 \%$ dithiothreitol using a Virtis homogenizer for three periods of $30 \mathrm{~s}$ at low speed at $4{ }^{\circ} \mathrm{C}$. Cell walls were discarded after centrifugation at $1000 \mathrm{~g}$ for $10 \mathrm{~min}$. The supernatant was centrifuged at $48000 \mathrm{~g}$ for $30 \mathrm{~min}$ to separate particulate enzymes and a supernatant.

$\beta$-Glucan synthase assay. The complete assay mixture (total volume $370 \mu \mathrm{l}$ ) contained $0 \cdot 3 \mathrm{nmol}$ UDP $\left[{ }^{14} \mathrm{C}\right] \mathrm{glucose}$ (7.4 MBq mol-1 ; CEA Saclay, France), $0.1 \mu \mathrm{mol}$ dithiothreitol, $2 \mu \mathrm{mol}$ cellobiose, $400 \mathrm{nmol}$ UDP-

\footnotetext{
Abbreviations: AMP-PCP, adenylyl ( $\beta, \gamma$-methylene)diphosphonate; GMP-PCP, guanylyl $(\beta, \gamma-$ methylene)diphosphonate; ATP-S, adenosine 5'-O-(3-thiotriphosphate); GTP-S, guanosine $5^{\prime}-O-(3-$ thiotriphosphate).
} 
[ ${ }^{12} \mathrm{C}$ ]glucose, $4 \mu \mathrm{mol} \mathrm{MgCl}_{2}, 25 \mathrm{mM}$-PIPES/Tris buffer $\mathrm{pH} 6.0$ and $100 \mu$ freshly isolated enzyme preparation ( $\sim 200 \mu \mathrm{g}$ protein). The mixtures were incubated at $27^{\circ} \mathrm{C}$ for $30 \mathrm{~min}$. Reactions were terminated by heating the tubes for $2 \mathrm{~min}$ in a boiling water bath. After addition of cellulose powder (10 to $20 \mathrm{mg}$ ) and $2 \mathrm{ml}$ water, the mixture was filtered through glass filters (Whatman GF/C, $2.4 \mathrm{~cm}$ ). Residue on the filter was washed with $40 \mathrm{ml}$ water, followed by $20 \mathrm{ml}$ methanol/chloroform $(2: 1, \mathrm{v} / \mathrm{v})$ and $40 \mathrm{ml}$ ethanol. Radioactivity of dried filters was determined in an Intertechnique SL 33 scintillation counter.

Digitonin treatment. The particulate fraction (pellet $48000 \mathrm{~g}, 30 \mathrm{~min}$ ) was resuspended in extraction buffer. A $1 \mathrm{ml} \mathrm{sample}$ of the original fraction was mixed with $1 \mathrm{ml}$ digitonin solution ( $5 \mathrm{or} 20 \mathrm{mg} \mathrm{ml}^{-1}$ ). Mixtures were kept at $4{ }^{\circ} \mathrm{C}$ for $30 \mathrm{~min}$, then centrifuged at $48000 \mathrm{~g}$ for $30 \mathrm{~min}$. The supernatant $(2 \mathrm{ml})$ was used as the soluble fraction and the treated pellet was resuspended in $2 \mathrm{ml}$ extraction buffer.

Density gradient fractionation. Particulate enzymes $(2 \mathrm{ml})$ were layered over a linear density gradient $(32 \mathrm{ml})$ of $20 \%$ to $50 \%(\mathrm{w} / \mathrm{w})$ sucrose containing $0.01 \mathrm{M}$-Tris/ $\mathrm{HCl} \mathrm{pH} 7.2$ and $0.001 \mathrm{M}$-EDTA and centrifuged at $4{ }^{\circ} \mathrm{C}$ in a Beckman L5-50 (SW 27 rotor) at 25000 r.p.m. for $3 \mathrm{~h}$. Gradients were cut into $1.5 \mathrm{ml}$ fractions and the sucrose concentration was determined by refractometry.

Chemicals. AMP-PCP, GMP-PCP, ATP- $\gamma-S$ and GTP- $\gamma-S$ were purchased from Boehringer-Mannheim.

\section{RESULTS}

\section{Action of nucleotides and nucleotide analogues}

The effect of ATP or GTP on glucan synthesis was dependent on the $\mathrm{pH}$ of the incubation medium (Fig. 1). Stimulation (expressed as the percentage of activity without ATP or GTP) was maximal at the optimal pH for glucan synthase activity, i.e. pH 6 (Fèvre \& Dumas, 1977). The stimulative effect of ATP and GTP was decreased by increasing the $\mathrm{pH}$ of the enzyme assay and was nearly lost at $\mathrm{pH} 8.4$.

As the stimulation of glucan synthesis could be mediated by phosphorylation, different nucleotide analogues were tested. AMP-PCP, GMP-PCP, ATP-S and GTP-S were used at concentrations ranging from $10^{-6} \mathrm{M}$ to $10^{-3} \mathrm{M}$. As previously noticed (Fèvre, 1983), maximal stimulation provoked by ATP was observed at about $5 \times 10^{-4} \mathrm{M}$; AMP-PCP was less effective, inducing only a slight increase at $10^{-3} \mathrm{M}$. ATP-S stimulated glucan synthesis with the maximal effect at $1-5 \times 10^{-4} \mathrm{M}$, but the stimulation was lower than that produced by the nucleotide:

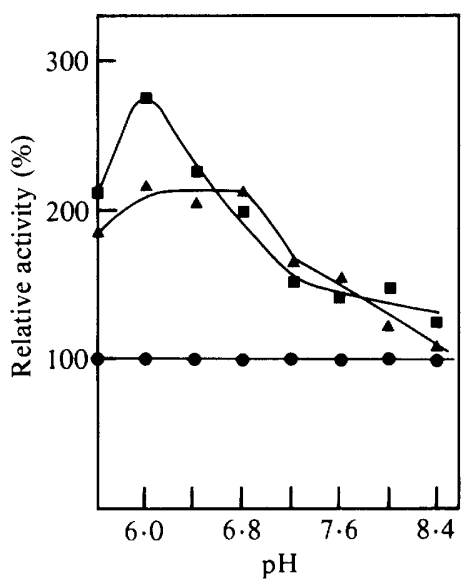

Fig. 1

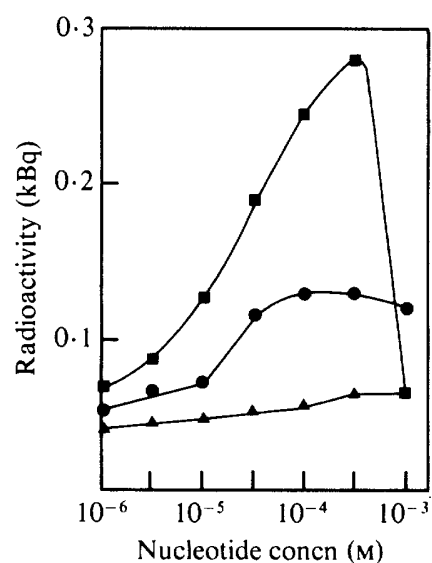

Fig. 2

Fig. 1. Effects of ATP and GTP on glucan synthase activity according to the pH of the assay. The relative activity is expressed as the percentage of the activity observed without ATP or GTP. 1 , ATP $\left(5 \times 10^{-5} \mathrm{M}\right) ; \Delta$, GTP $\left(5 \times 10^{-5} \mathrm{M}\right) ; 0$, control.

Fig. 2. Effects of nucleotides and nucleotide analogues on glucan synthase activities. $\square$, ATP; ATP-S; $\triangle$, AMP-PCP. 
twofold for ATP-S instead of 4-2-fold for ATP (Fig. 2). Similar results were obtained with GTP and its analogues. GTP at $5 \times 10^{-4} \mathrm{M}$ produced a 5.4-fold stimulation, while at that concentration GTP-S stimulation was only threefold and GMP-PCP was ineffective. The $K_{\text {a }}$ (nucleotide concentration for half-maximal stimulation) was comparable for the nucleotides and their analogues, being between 10 and $50 \mu \mathrm{M}$, values similar to those found for activation of other systems (Aloni et al., 1983; Notario et al., 1982).

As ATP and GTP presented similar characteristics of stimulation of glucan synthase (i.e. comparable $K_{\mathrm{a}}$ values and $\mathrm{pH}$ response), it was interesting to know whether their action would be synergistic. Glucan synthesis was assayed in the presence of various concentrations of GTP, in the presence or absence of $5 \times 10^{-5} \mathrm{M}$-ATP (Fig. 3). The presence of ATP did not significantly increase the stimulation produced by GTP. GMP-PCP at a concentration of $10^{-4} \mathrm{M}$, which alone has no action, did not increase or inhibit ATP stimulation. Similar results were obtained when GTP at $5 \times 10^{-5} \mathrm{M}$ or AMP-PCP at $10^{-4} \mathrm{M}$ were added to the synthases assayed in the presence of increasing concentrations of ATP.

ATP and GTP were tested in the presence of ATP-S and GTP-S which showed similar patterns of activation when used alone. The stimulation of glucan synthesis by GTP-S was not increased by the presence of $5 \times 10^{-5} \mathrm{M}-\mathrm{GTP}$. The stimulation of glucan synthesis by ATP-S and ATP was partially additive (Fig. 4).

\section{Effect of nucleotides on soluble enzymes}

Nucleotide stimulation is decreased in the presence of high digitonin concentrations during the assays (Fèvre, 1983), so the action of nucleotides on enzymes solubilized by digitonin treatment (Fèvre, 1979b) was examined.

When particulate enzymes were treated with digitonin at 2.5 or $10 \mathrm{mg} \mathrm{ml}^{-1}$, at least $70 \%$ of the proteins were recovered in the supernatant (Table 1). The glucan synthase activities recovered in the pellets and supernatants were higher than those in the original particulate fraction, confirming the presence of latent enzymes entrapped in vesicles (Fèvre, 1979b).

The higher digitonin concentration tested was inhibitory as only $58 \%$ of the activity measured with $2.5 \mathrm{mg}$ digitonin $\mathrm{ml}^{-1}$ was recovered. While the enzymes of the original particulate fraction

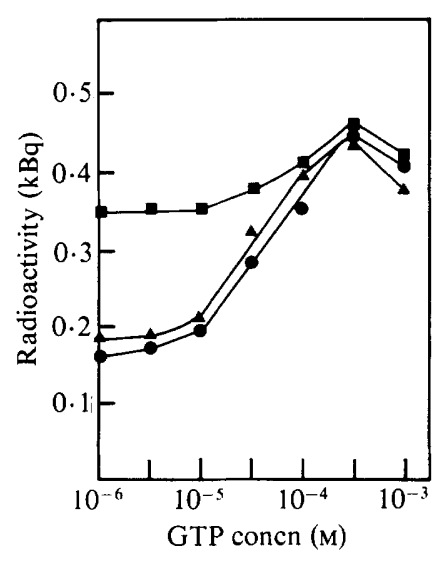

Fig. 3

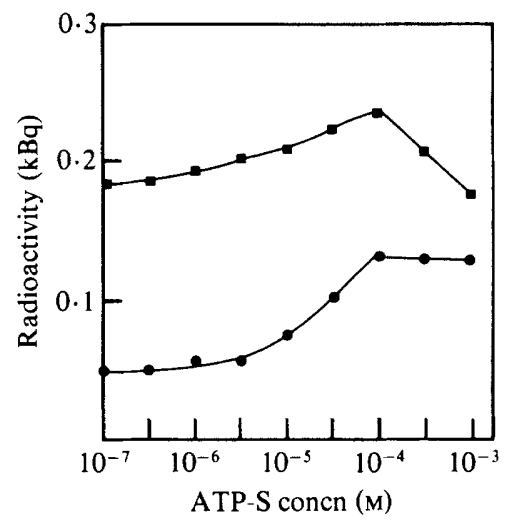

Fig. 4

Fig. 3. Effects of ATP and GMP-PCP on the stimulation of glucan synthase activity produced at different concentrations of GTP. The concentration of GTP was varied in the absence (O) or presence of $5 \times 10^{-5} \mathrm{M}-\mathrm{ATP}(\mathbf{\square})$ or $10^{-4} \mathrm{M}-\mathrm{GMP}-\mathrm{PCP}(\boldsymbol{\Lambda})$.

Fig. 4. Effects of ATP on the stimulation of glucan synthase activity produced by ATP-S. The concentration of ATP-S was varied in the absence $(O)$ or presence $(\square)$ of $5 \times 10^{-5} \mathrm{M}$-ATP. 
Table 1. Effect of nucleotides on particulate and solubilized $\beta$-glucan synthases

The original particulate fraction was treated for $30 \mathrm{~min}$ at $4{ }^{\circ} \mathrm{C}$ with 2.5 or $10 \mathrm{mg}$ digitonin $\mathrm{ml}^{-1}$ (final concentration). After centrifugation at $48000 \mathrm{~g}$ for $30 \mathrm{~min}$, treated pellets and soluble fractions were recovered and assayed for glucan synthase activity in the presence or absence of nucleotides. ATP and GTP were used at a concentration of $5 \times 10^{-5} \mathrm{M}$.

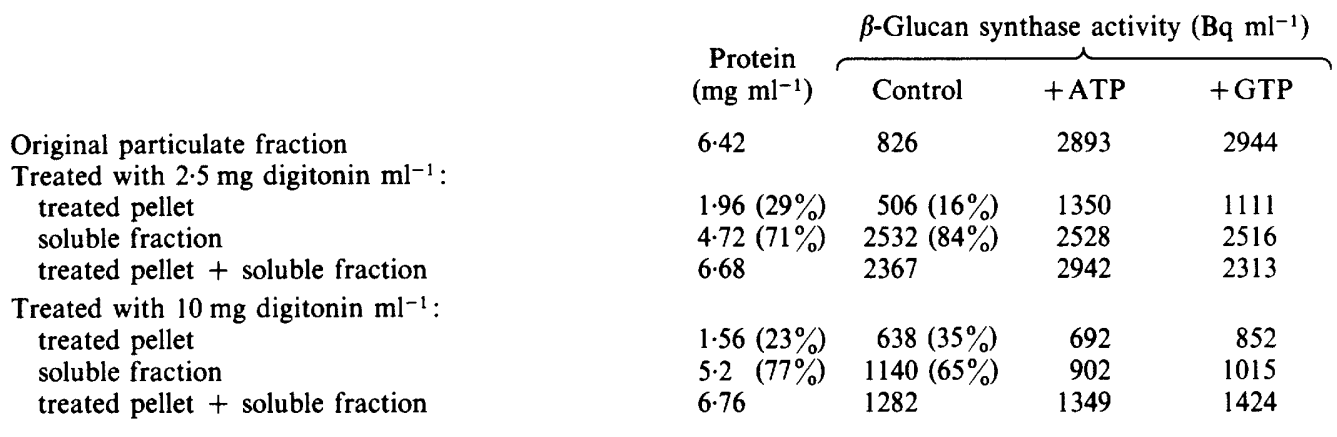

were stimulated (3.5- to 3.65-fold) by the presence of ATP or GTP at $5 \times 10^{-5} \mathrm{M}$, these nucleotides had no stimulative effects on the soluble enzymes and there was even a slight inhibition (Table 1). The enzymes remaining in the digitonin-treated pellet were however stimulated $(2 \cdot 2-$ to $2 \cdot 6$-fold).

The possibility that components essential for glucan synthesis and nucleotide stimulation were separated following digitonin treatment was also investigated. Enzymes of the digitonintreated pellet and the soluble fraction were mixed and assayed. The activities measured were comparable to those observed in the soluble fraction. They did not correspond to the sum of the activities found in the two fractions, probably because of the action of digitonin present in the soluble fraction on the enzymes of the treated pellet. Nucleotides slightly stimulated glucan synthesis. The addition of $\mathrm{CaCl}_{2}(0.25$ to $3 \mathrm{mM})$ did not increase glucan synthesis or enhance nucleotide stimulation: on the contrary, an inhibition of 15 to $20 \%$ was observed in the presence of $2 \mathrm{~mm}-\mathrm{CaCl}_{2}$ (data not shown).

\section{Separation of the membranes by sucrose density gradient centrifugation}

As the nucleotide stimulation is restricted to membrane-bound glucan synthases, it was interesting to identify the membranes involved in this process. Particulate enzymes were fractionated by isopycnic centrifugation in a sucrose density gradient, in which endoplasmic reticulum, plasma membrane and mitochondria are recovered at densities of $1 \cdot 10,1 \cdot 16$ and $1.21 \mathrm{~g} \mathrm{ml}^{-1}$ respectively (Girard \& Fèvre, 1984). Glucan synthases assayed at $0.85 \mu \mathrm{M}$-uridine 5'-diphosphate glucose (UDPglucose) mainly equilibrated in the plasma membrane fraction; a small peak of activity was associated with the endoplasmic reticulum. When the assays were done in the presence of $10^{-4} \mathrm{M}$-ATP or -GTP, stimulation of glucan synthesis occurred in all the fractions (Fig. 5), but to different extents in the different membrane fractions. Glucan synthases associated with the plasma membrane were stimulated $1 \cdot 5$-fold whereas those associated with the endoplasmic reticulum were stimulated three- to fourfold.

\section{DISCUSSION}

The observations presented here and those in a previous study (Fèvre, 1983) show that ATP and GTP have a similar pattern of stimulation of glucan synthesis, viz comparable $K_{\mathrm{a}}$ values, and similar levels of stimulation and $\mathrm{pH}$ dependence. Of the four nucleotide analogues tested, AMPPCP and GMP-PCP were completely inactive, suggesting that the stimulation might occur by a phosphorylation process. However, the analogues ATP-S and GTP-S were active, with apparent

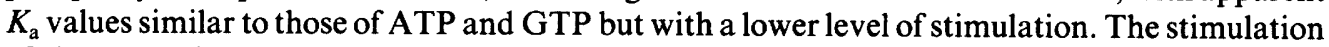
of glucan synthases is evidently independent of the nature of the nucleotide portion of the activa- 


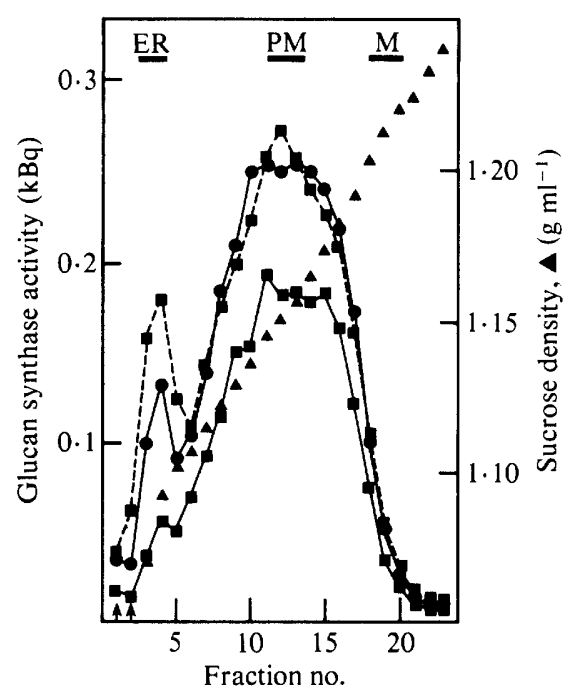

Fig. 5. Effects of ATP or GTP on glucan synthase activity of particulate enzymes fractionated by isopycnic centrifugation in sucrose gradient. ER, PM and $\mathbf{M}$ indicate the positions of the biochemical markers of the endoplasmic reticulum, plasma membrane and mitochondria, respectively. Glucan synthases were assayed in the absence ( $\square-\square$ ) or presence of $10^{-4} \mathrm{M}-\mathrm{ATP}(\square---\square)$ or $10^{-4} \mathrm{M}-\mathrm{GTP}$ (O).

tor as guanosine or adenosine are effective. The main effect is probably due to the integrity of the three phosphate groups: nucleoside diphosphates are poor activators (Fèvre, 1983) and the substitution of the $\beta-\gamma$ oxygen leads to inefficiency of the nucleotide. The stimulation produced by the nucleotides and their effective analogues were not additive.

In Saprolegnia, the activation of glucan synthases by ATP, GTP, ATP-S or GTP-S but not by other analogues indicates that the process involved in stimulation is different to those postulated by Cabib's group (Shematek et al., 1980; Notario et al., 1982). In Saccharomyces, activators (i.e. inorganic pyrophosphate, nucleoside diphosphate, nucleotide or nucleotide analogues) may interact with a functional site for the pyrophosphate residue and a binding site for the nucleoside moiety on the enzyme or on a regulatory protein. In Saprolegnia, the lack of stimulative effect of nucleotides on digitonin-solubilized glucan synthases indicates that these stimulators do not act directly on the enzymes and that the integrity of the membranes is necessary for stimulation. Aloni et al. (1983) have shown that solubilized enzymes of Acetobacter are stimulated by the cooperative action of GTP and a soluble protein factor. The association of the enzyme and the protein factor is promoted by polyethylene glycol or $\mathrm{Ca}^{2+}$, which are known to induce membrane fusion.

In our system, we have no evidence for the involvement of a soluble compound in the stimulation of glucan synthesis: association of solubilized enzymes with digitonin-treated membranes did not increase the action of nucleotides. It is, however, possible that an enzyme activity or a compound involved in the stimulation by nucleotide could be inactivated by the digitonin treatment.

Recently, Godelaine \& Beaufay (1983) and Paiement \& Bergeron (1983) have shown that GTP stimulates glycosylation in rat liver microsomes. This action is localized on the endoplasmic reticulum membranes and is due either to fusion of the membranes or to an increase of the permeability of the membranes to the substrate. In Saprolegnia, nucleotides stimulate only membrane-bound enzymes and, more particularly, those of the endoplasmic reticulum. It is possible that in Saprolegnia ATP or GTP increases the accessibility (translocation) of the substrate to the enzyme, by changing the properties of the membranes. The glucan synthases are probably fixed on the inner face of the endoplasmic reticulum membranes and not accessible to the substrate; this would explain the low activity found in the density gradient. Stimulators, by 
modifying the permeability of the membranes, would permit the translocation across the membranes of UDPglucose to the synthases: this would explain the peak of glucan synthase activity found in density gradients at the level of the endoplasmic reticulum. The effect of nucleotides on membranes is presently under investigation.

I would like to thank Dr Graham W. Gooday, University of Aberdeen, UK, for critically reading the manuscript. This research was supported by the Direction de la Recherche - Aide à la Recherche Universitaire - Biologie, 1982-1983.

\section{REFERENCES}

Aloni, Y., Delmer, D. P. \& Benziman, M. (1982). Achievement of high rates of in vitro synthesis of 1,4$\beta$-D glucan: activation by cooperative interaction of the Acetobacter xylinum enzyme system with GTP, polyethylene glycol and a protein factor. Proceedings of the National Academy of Sciences of the United States of America 79, 6448-6452.

Aloni, Y., Cohen, R., Benziman, M. \& Delmer, D. (1983). Solubilization of the UDP-glucose : 1,4- $\beta$-Dglucan 4- $\beta$-D glucosyltransferase (cellulose synthase) from Acetobacter xylinum. A comparison of regulatory properties with those of the membrane bound form of the enzyme. Journal of Biological Chemistry 258, 4419-4423.

BARTNICKI-GARCIA, S. (1968). Cell wall chemistry, morphogenesis and taxonomy of fungi. Annual Review of Microbiology 22, 87-105.

FÈVRE, M. (1979a). Glucanases, glucan synthases and wall growth in Saprolegnia monoica. In Fungal Walls and Hyphal Growth, pp. 225-263. Edited by J. H. Burnett \& A. P. J. Trinci. Cambridge: Cambridge University Press.

FĖVRE, M. (1979b). Digitonin solubilization and protease stimulation of $\beta$-glucan synthetases of Saprolegnia. Zeitschrift für Pflanzenphysiologie 95 , 129-140.

FÈvre, M. (1983). Nucleotide effects on glucan synthesis activities of particulate enzymes from Saprolegnia. Planta 159, 130-135.

FÈvRE, M. \& Dumas, C. (1977). $\beta$-Glucan synthetases from Saprolegnia monoica. Journal of General Microbiology 103, 297-306.

FÈvre, M. \& Rougier, M. (1981). $\beta 1-3$ and $\beta 1-4$ glucan synthesis by membrane fractions from the fungus Saprolegnia. Planta 151, 232-241.

GirarD, V. \& FÈVRE, M. (1984). $\beta 1-4$ and $\beta 1-3$ glucan synthetases are associated with the plasma membrane of the fungus Saprolegnia. Planta 160, 400-406.

Godelaine, D. \& Beaufay, H. (1983). The Dolichol pathway of protein glycosylation in rat liver. Evidence that GTP promotes transformation of endogenous dolichyl phosphate into dolichyl pyrophosphoryl- $N$-acetylglucosamine in stripped rough microsomes. European Journal of Biochemistry 131. $667-670$.

MACHLIS, L. (1953). Growth and nutrition of water molds in the subgenus Euallomyces. II. Optimal composition of the minimal medium. American Journal of Botany 40, 449-460.

Notario, V., KaWAi, H. \& CABIB, E. (1982). Interaction between yeast $\beta$ - $(1-3)$ glucan synthetase and activating phosphorylated compounds. A kinetic study. Journal of Biological Chemistry 257, 19021905.

PAiement, J. \& Bergeron, J. J. (1983). Localization of GTP-stimulated core glycosylation to fused microsomes. Journal of Cell Biology 96, 1791-1796.

ShemateK, E. M. \& CABiB, E. (1980). Biosynthesis of the yeast cell wall. II Regulation of $\beta(1-3)$-glucan synthetase by ATP and GTP. Journal of Biological Chemistry 255, 895-902.

Shematek, E. M., BraAtz, J. A. \& Cabib, E. (1980). Biosynthesis of the yeast cell wall. I Preparation and properties of $\beta(1-3)$ glucan synthetases. Journal of Biological Chemistry 255, 938-942. 